\title{
Plevral efüzyonla prezente olan romatoid artrit (Olgu sunumu)
}

\author{
Rheumatoid arthritis presenting as pleural effusion (Case report) \\ İsa Döngel*, Mehmet Bayram, Emrullah Hayta, Salih Yıldırım, Hakan İmamoğlu, \\ Faysal Duksal
}

Göğüs Cerrahisi Anabilim Dalı (Yrd. Doç. Dr. İ. Döngel), Süleyman Demirel Üniversitesi Tıp Fakültesi, TR-32260 Isparta, Göğüs Hastalıkları Kliniği (Dr. M. Bayram, Dr. F. Duksal), Anestezi Kliniği (Dr. S. Yıldırım), Radyoloji Kliniği (Dr. H. İmamoğlu), Sivas Numune Hastanesi, TR58040 Sivas, Fiziksel Tıp ve Rehabilitasyon Anabilim Dalı (Yrd. Doç. Dr. E. Hayta), Cumhuriyet Üniversitesi Tip Fakültesi, TR-58140 Sivas,

\section{Özet}

Romatoid artrit (RA) nüfusun yaklaşık \%0,3-1,5'inde görülen etiyolojisi bilinmeyen, eklemlerden iç organlara kadar vücudun farklı bölgelerinde tutulumla karakterli kronik otoimmün bir hastalıktır. Plöropulmoner tutulum ikinci sıklıkla görülen tutulum olup en başta gelen mortalite nedenidir. Plöropulmoner tutulum RA tanısı almadan önce ortaya çıkarsa, ayırıcı tanıda düşünülmeyip gözden kaçabilir. Başlangıç semptomu olarak plevral efüzyon, solunum sıkıntısı ve son altı aydır devam eden göğüs ağrısı şikâyetleri ile gelen ve takibinde RA tanısı alan olguyu literatür bilgileri ışığında sunmayı amaçladık.

Anahtar sözcükler: Romatoid artrit, plevral efüzyon, plörit

\begin{abstract}
Rheumatoid arthritis (RA) is a chronic autoimmune disease with unknown aetiology which effects a variety from joints to internal organs and other sites of organism. It's seen in $0.3-1.5 \%$ of population. Pleuropulmonary involvement which is the second frequent involvement is the major cause of mortality. If the pleuropulmonary involvement exists before the diagnosis of rheumatoid arthritis, it may be overlooked. We aimed to present a case with pleural effusion, respiratory distress and chest pain lasting for 6 months as initial symptoms and diagnosed as rheumatoid arthritis in follow up on the light of literature data.
\end{abstract}

Keywords: Rheumatoid arthritis, is pleural effusion, pleurit

Geliş tarihi/Received: 14 Aralık 2011; Kabul tarihi/Accepted: 19 Haziran 2012

\section{*Iletişim adresi:}

Dr. İsa Döngel, Süleyman Demirel Üniversitesi, Tıp Fakültesi, Göğüs Cerrahisi Anabilim Dalı, Isparta. TR-32260. E-posta: drdongel@ hotmail.com

\section{Giriş}

Romatoid artrit (RA) toplumda en s1k görülen, otoimmün ve inflamatuar bir hastalıktır. En çok kronik, eklem hastalığı görünümünde olmakla birlikte çeşitli eklem dışı bulguları da olan sistemik bir hastalıktır [1, 2]. Romatoid artrit'li hastalarda plöropulmoner tutulum, akciğerde romatoid nodüller, interstisyel pnömonitis ve fibrozis, küçük hava yolları hastalığı, pulmoner vaskülit, bronşiolitis, pulmoner hipertansiyon ve plevral tutulum şeklinde farklı formlarda karşımıza çıkabilmektedir. Plöropulmoner tutulum RA'nın en sık görülen eklem dışı bulgusudur [3]. Klinik olarak RA'ya bağlı plevral efüzyon \%3-5 oranında görülürken, otopsi çalışmalarında RA tanısı olan hastaların \%3573'ünde plevral tutulum tespit edilmiştir [4]. Plevral tutulum RA'lı hastaların yaklaşık 
\%20'sinde artrit başlangıcı ile aynı anda gelişir [5]. Plöropulmoner tutulum RA'nın genellikle eklem bulgularından sonra görülmesine karşın, nadiren başlangıç bulgusu olabilir, bu durumda klinisyen ayırıcı tanıda yanılgıya düşebilir [6]. Bu sunumda plöropulmoner hastalık semptomları ile başvuran, plevral efüzyon saptanan ve takibinde eklem bulguları ile RA tanısı konulan olgu tartışılacaktır.

\section{Olgu sunumu}

Kliniğimize göğüs ağrısı ve nefes darlığı şikâyetleri ile gelen, sigara ve alkol kullanmayan, 64 yaşında kadın hastanın fizik muayenesinde sağ hemitoraksta matite vardı ve dinlemekle solunum sesleri azalmıştı. Laboratuvar bulgularından; CRP: $1,34 \mathrm{mg} / \mathrm{dL}$, sedimentasyon hızı (ESR): $88 \mathrm{~mm} / \mathrm{h}$ idi. Plevral mayi; glukoz: $29 \mathrm{mg} / \mathrm{dL}$, LDH: $650 \mathrm{mg} / \mathrm{dL}$, protein: 5,4mg/dL, albümin: $2,7 \mathrm{mg} / \mathrm{dL}, \mathrm{pH}: 7,2$ eksuda vasfında, ARB: negatif saptand. Solunum fonksiyon testinde: $\mathrm{FEV}_{1}$ 1,31 (\%76), $\mathrm{FEV}_{1} / \mathrm{FVC} 68$ (\%88) saptandı. Radyolojik olarak sağ hemitoraksda plevral efüzyonla uyumlu görünüm mevcuttu (Resim 1, 2). Hastaya sağ posterior 7. interkostal aralıktan tüp torakostomi uygulandı. Klinik ve radyolojik rahatlama sağlandıktan sonra, malignite ekartasyonu amacıyla yapılan torakoskopik plevra biyopsisi kronik fibrinöz plörit olarak raporlandı. Plevral sıvı sitolojisi kanamalı fibrinöz ve granüler zeminde bol polimorf nüveli lökosit bazıları iğsi şekilli histiyositler ve multi nükleer dev hücreler olarak raporlandı. İstenilen plevral sıv1 ARB ve bakteriyolojik kültürlerinde üreme olmadı. Fleksibl bronkoskopide tüm segmentler açık olarak görüldü, endobronşiyal lezyon görülmedi. İki ay sonra hastanın plevral efüzyonunun tekrarlaması, özellikle el eklemlerinde şişlik ve ağrı şikâyetlerinin başlaması nedeni ile kliniğimize tekrar yatırıldı. Romatoid artrit'e bağlı plevral tutulum ön tanısı ile plevral sıv1 ve kandan romatoid faktör (RF) gönderildi, sırasıyla 37,3IU/mL, 60,2IU/mL ölçüldü. Hasta Fizik Tedavi ve Rehabilitasyon (FTR) Kliniği'ne RA ön tanısıyla danışıldı. Hastanın FTR kliniğindeki fizik muayesinde her iki el bileğindei sol 3. ve 4. metakarpofarangial (MKF) eklemde, sağ 3.MKF aktif artriti her iki elde ulnar kuğu boynu deformitesi saptanmış olup hastadan antenior-posterior ve lateral el grafisi ve kan tahlili istendi. Yapılan radyolojik tetkiklerde her iki unlar styloid çıkıntıda erozyon, el karpal kemiklerde eklem aralığında daralma, kan tahlilinde anti CCP değeri 115,26U/mL ANA (-) ESR 94mm/h CRP 1,76mg/dL çıkması üzerine hastaya mevcut klinik şikayetleri ve bulguları doğrultusunda RA tanısı konuldu. Plevral sıvının RA'nın plevral tutulumuna bağlı olduğu anlaşıldı. Prednizolon (10mg/gün) ve leflunomid (ilk 3 gün $100 \mathrm{mg} /$ gün yükleme dozunu takiben $20 \mathrm{mg} /$ gün idame dozunda) tedavisi başlandı. Takibinin yirmi dördüncü ayında klinik ve radyolojik olarak stabil seyretmektedir.

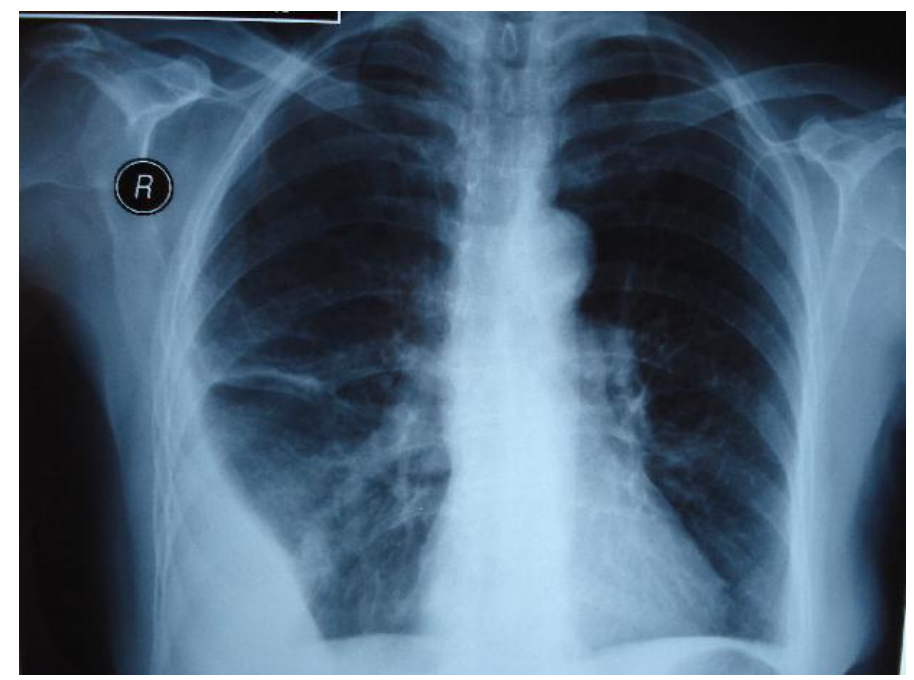

Resim 1. Hastanın PA akciğer grafisinin görüntüsü. 


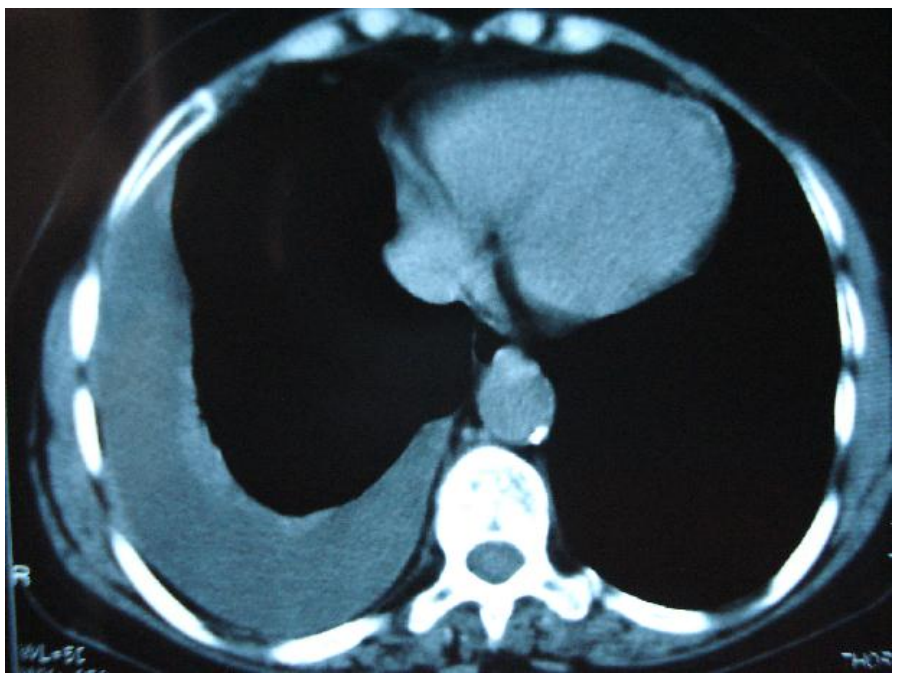

Resim 2. Hastanın tomografik görüntüsü.

\section{Tartışma}

Romatoid artrit 4-5. dekatta pik yapan, kadınlarda daha sık görülen kronik inflamatuar, otoimmün bir hastalıktır [7]. RA'da ciddi eklem dışı tutulum mortalitenin en önemli belirleyicisidir. Akciğerler içerdiği yoğun bağ dokusu ve yoğun damarlanması nedeni ile kollajen doku hastalıklarında sık tutulur ve bu tutulum plevra, hava yolları veya vasküler lezyonlar şeklinde olabilir [8]. Multi genetik faktörler hastalığa duyarlı kişilerde, klinik bulguların ortaya çıkışında muhtemelen tetikleyici rol oynamaktadır. Romatoid artrit'de plöropulmoner tutulumun patogenezi henüz tam olarak açıklanamamıştır, fakat immünopatolojik mekanizmaların sorumlu olduğu düşünülmektedir. Romatoid artrit genellikle kadınlarda daha sık görülmesine karşın eklem dışı tutulum erkeklerde daha fazla görülmektedir [1, 2]. Olgumuz 64 yaşında bir kadındı ve RA'in ilk bulgusu plevral efüzyondu. Romatoid artrit ilk olarak plevral efüzyon bulguları ile prezente olduğu zaman ayırıcı tanıda RA düşünülmeyebilir. Bu durumda yanılgılara, gereksiz tetkik ve tahlil yaptırılmasına hatta yanlış teşhis ile hastanın ve hekimin zaman kaybına neden olabilmektedir.

Romatoid artrit'li hastaların direk PA akciğer grafilerinde \%2-5 oranında, toraksın yüksek rezolüsyonlu tomografilerinde (YRBT) \%70'e varan oranda patolojiler saptanmaktadır. Plöropulmoner tutulumu değerlendirmek için YRBT gibi daha sensitif yöntemler kullanılmalıdır, YRBT plöropulmoner tutulumun lokalizasyonunu ve yaygınlığını belirlemede kullanışlı bir yöntemdir [9]. Olgumuzun çekilen tomografisinde her iki hemitoraks orta ve alt loblarda fibrotik çekintiler, sol akciğer alt lob anterior segmentte hava kisti ve sağda plevral efüzyonla uyumlu görüntü izlendi. RF yüksek titrede pozitif olan olgularda plevral efüzyon ve romatoid pulmoner nodül daha sik görülür. RA'da plevral sıvı aseptik düşük $\mathrm{pH}$, düşük glukoz ve yüksek LDH ile birlikte eksudatif karakterdedir. Bu özellikteki sıvılarda öncelikli olarak bakteriyel ampiyem, tüberküloz ve malignite düşünülmelidir [10]. Olgumuzda plevral sıvı seröz, bulanık eksudatif karakterde olduğu için, istenilen plevral sıvı ARB ve bakteriyolojik kültürlerinde üreme olmad1. Malignite ekartasyonu amaciyla yapılan torakoskopik plevra biyopsisi kronik fibrinöz plörit olarak raporlandı. Plevral sivı ve RF düzeyleri sırasıyla 37,3IU/mL, $60,2 \mathrm{IU} / \mathrm{mL}$ ölçüldü. Olgumuzda plevral efüzyon dişında, romatoid pulmoner nodüle rastlanmadı. İlk etapta RA düşünülmediği için RA tanısı yaklaşık iki ay sonra eklem bulguları ve plevral efüzyonun tekrarlamasıyla konuldu. Olgumuza prednizolon ve leflunomid tedavisi başlandı, plevral efüzyonu geriledi. Takibinin yirmi dördüncü ayında stabil seyretmektedir. 
Plevral efüzyon nadirde olsa RA 'nın ilk bulgusu olabileceği, tekrarlayan ve sebebi bulunamayan eksudatif karakterli plevral efüzyonların ayırıcı tanısında Romatoid artrit'inde düşünülmesi gerektiği kanaatindeyiz.

\section{Kaynaklar}

1. Amital A, Shitrit D, Adir Y. The lung in rheumatoid arthritis. Presse Med 2010; 40: 31-48.

2. De Clerck LS. B lymphocytes and humoral immune responses in rheumatoid arthritis. Clin Rheumatol 1995; 14: 14-8.

3. Hatemi G, Yazıcı H.Romatoid Artrit Kliniği. Türkiye Klinikleri J Int Med Sci 2006; 2: 12-7.

4. Yalçın P. Romatoid Artrit Harris ED, Budd CR, Firestein GS çeviri eds. Arasıl T. Kelley Romatoloji 7. bask1. Güneş Kitabevi 2006; 66: 1043-78.

5. Tanoue LT. Pulmonary manifestations of rheumatoid arthritis. Clin Chest Med 1998; 19: 667-85.

6. Carotti M, Salaffi F, Manganelli P, Salvolini L, Bichi Secchi E, De Berardinis S. The subclinical involvement of the lung in rheumatoid arthritis: evaluation by high-resolution computed tomography. Rheumatism 2001; 53: 280-8.

7. Çimen F, Ulukavak Ciftci T, Dulkar Dursun G. Romatoid artrite bağl1 plöropulmoner tutuluma bir örnek: Romatoid plevral efüzyon (Bir olgu nedeniyle). Solunum Hastalıkları 2001; 12: 233-7.

8. Walker WC, Wright V. Rheumatoid pleuritis. Ann Rheum Dis 1967; 26: 467-74.

9. Cortet B, Flipo RM, Remy-Jardin M, Coquerelle P, Duquesnoy B, Remy J, Delcambre B. Use of high resolution computed tomography of the lungs in patients with rheumatoid arthritis. Ann Rheum Dis 1995; 54: 815-9.

10. Yüksel C, Çelik R, Cangır AK, Sak SD, Kavukcu HŞ. Plevral sıvı sitolojisi ve açık akciğer biyopsisi ile tanı konulan bir romatoid artrit olgusu. Ankara Üniversitesi T1p Fakültesi Mecmuası 2003; 56: 55-8. 